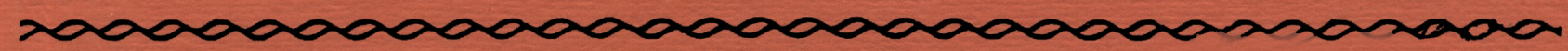

Southern gournal

al

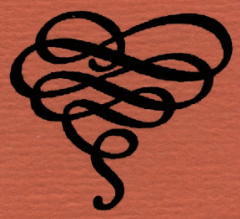

Volume 2, Number 1

December 1970

Published by

Southern Agricultural Economics Association

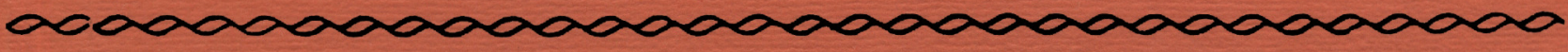




\section{EDITORIAL COUNCIL}

J. ROD MARTIN, USDA, Texas A\&M University, Editor

M. LLOYD DOWNEN, University of Tennessee

DONALD L. HENRY, Federal Reserve Bank of St. Louis

DALE M. HOOVER, North Carolina State University

JAMES E. MARTIN, Virginia Polytechnic Institute

JOHN R. MOORE, University of Maryland

JOSEPH C. PURCELL, Georgia Agricultural Experiment Station

WESLEY G. SMITH, Tennessee Valley Authority

JOHN G. STOVALL, USDA, University of Kentucky

KENNETH R. TEFERTILLER, University of Florida

LUTHER G. TWEETEN, Oklahoma State University

FRED H. TYNER, University of Florida

DA, University of Kentucky

LLER, University of Florida

Oklahoma State University

rsity of Florida

, Texas Tech University

UHN G. SIUVALL, USDA, University of Kentucky

ENNETH R. TEFERTILLER, University of Florida

UTHER G. TWEETEN, Oklahoma State University

RED H. TYNER, University of Florida

ILLARD F. WLLIAMS, Texas Tech University

JUHN G. SIUVALL, USDA, University of Kentucky

KENNETH R. TEFERTILLER, University of Florida

LUTHER G. TWEETEN, Oklahoma State University

FRED H. TYNER, University of Florida

WILLARD F. WLLIAMS, Texas Tech University

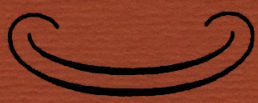

1 Economics

agricultural

hip dues are

are available

ry.Trazarar , Knoxville,
The Southern Journal of Agricultural Economics is published annually by the Southes Association.

Membership in the SAEA, consisting of persons and organizations having a professio economics, includes subscription to the journal. Regular membership dues are $\$ 3.00$. Ju $\$ 1.50$

The annual subscription rate for libraries and other institutions is $\$ 7.50$. Single copies at a price of $\$ 7.50$.

Please address all subscription, membership, and changes of address to Dr. Luther H.I of SAEA, Department of Agricultural Economics, The University of Tennessee, 


\section{CONTENTS}

Meshing Natural Resources Use and Development with Increasing Urbanization - W. B. Back

Urbanized Society Needs Met by Rural People - Lee Taylor

Emerging Agricultural Problems for the Decade Ahead - James G. Maddox

Farm Policy Requirements as Seen from the Perspective of Government - Don Paarlberg

Toward Farm Policy Requirements for the 1970's

to Improve the Well-being of Rural America - W. Neill Schaller

R. J. Hildreth

Policy Requirements in the Seventies:

A Farmer's Viewpoint - George C. Cartwright

Production Organization Implications of Agricultural

Industrialization - Odell L. Walker

Morphology, Modes of Behavior, and Measures of

Market Power: A Framework for Evaluating the

Impact of Industrialization of Southern Agriculture

on Markets and Market Structure - Richard A. King

Effects of Industrialization on Capital Requirements

for Southern Agriculture -- Don Bostwick

Foreign Economic Development: The Need and

How Well It Is Being Met - Ralph K. Davidson

University Assistance in Building Agricultural

Research Institutions in Southeast Asia -.

$A$ Case Analysis - Eldon D. Smith

Agricultural Development Effort Assessment:

The Colombian Case - James S. Plaxico 
The Cotton Program Under the Food and

Agriculture Act of 1965 - James Vermeer

The Distribution of Benefits from the 1968

Upland Cotton Program - Roger P. Hill

General Cropland Retirement: Effects on the South

of Retiring Low-Net-Return Acreage i's. Retiring

High-Cost Production - Glenn A. Zepp

Jerry A. Sharples

Part-Farm General Cropland Retirement: Effects

of Some Alternative Program Specifications -- George D. Irwin

Jerry A. Sharples

John H. Berry

The Optimum Geographic Location of Burlev

Tobacco Production within the Burley Belt - Verner Grise

Relationships of Labor Costs to Selected

Variables in Flue-Cured Tobacco Production -- Garnett L. Bradford

Off-Furm Income of People Involved in

Farming - Edward I. Reinsel

Simulated Effects of Use Value Assessment on

Property Tax Rates - Chauncey T.K. Ching

George E. Frick

The Federal Role in Small Area Farming - Neil R. Cook

Some Conceptual Problems in the Evaluation

of Water Pollution Damages - Burl F. Long

A Proposed Procedure for Distributing Assessments

Among Beneficiaries of Small Watershed Projects - Ronald D. Lacewell

Vernon R. Eidman

The Use of Central Place Theory and Gravity-Flow

Analysis to Delineate Economic Areas - W. W. Hall, Jr.

J. C. Hite

Quarterly Egg Production Estimators - Robert G. Hoffman

An Economic Appraisal of the U.S. Tung

Oil Economy - Jimmy L. Matthews

Abner W. Womack

Toward An Information System for Guiding Reseurch

in the Soybean Production Economy - J. B. Penn 
Empirical Testing of a Farm Firm Growth

Theory - Frederick J. Rafeld

Systems Analysis Approach to Selection of

Farm Equipment - James E. Osborn

Wendell C. Barrick

Price and the Structure of Freight Car

Ownership - Patrick P. Boles

John O. Gerald

A Numerical Example of the Practical Use

of Dummy Variables - Charles Sappington 